\title{
Growth Regulation and Suppression of Metastasis In the Congenitally Athymic Nude Mouse
}

\author{
Charles D. Stiles, Penelope E. Roberts, \\ Milton H. Saier Jr. and Gordon Sato
}

\author{
Department of Biology \\ John Muir College \\ University of California, San Diego \\ La Jolla, California 92037, U.S.A.
}

\section{Introduction}

The physiologically relevant site for studies on growth regulation is within intact modulated circuits which have evolved for maintenance of tissue and organ animal hosts. Animal cells in culture are disconnected from complex hormonally homeostasis (Furth, 1967). Paradoxically the most detailed information on growth control has been generated from studies on animal fibroblasts and lymphocytes grown in vitro. In the tissue culture environment, the growth of cloned populations of animal cells, in defined or semidefined media may be easily quantitated.

By studying the growth of established and cloned cell lines in heterologous animal hosts, the tactical advantages of tissue culture technology can be exploited in a biologically relevant framework. Heterologous cells can be recovered from animal hosts, identified and quantitated by virtue of their differential morphology, antigenic composition and karyotype. Clearly, however such studies can only be conducted in an immunologically tolerant host.

The congenitally athymic nude mouse does not display the cell mediated immune response and never rejects heterologous skin grafts (For review, see Rygaard, 1973). We have examined the capacity of nude mice to support and control the growth of a variety of heterologous tissue culture cell lines. This paper will deal with the results of these studies which demonstrate (1) that a variety of epithelioid and fibroblastic cell lines which grow forever in vitro do not grow tumors in nude mice; (2) that the failure of cell lines to grow tumors in nude mice is an authentic growth regulatory response; (3) that the growth behavior of cells in tissue culture is not a reliable indicator of tumorigenic potential; and (4) that the capacity of tumor cells to grow in suspension, invade surrounding tissues and develop secondary metastases possibly requires a thymus dependent function. 


\begin{tabular}{|c|c|c|c|c|}
\hline Category & $\begin{array}{l}\text { Cell line } \\
\text { or strain }\end{array}$ & $\begin{array}{l}\text { Tissure of } \\
\text { origin }\end{array}$ & $\begin{array}{l}\text { Transforming } \\
\text { agent }\end{array}$ & $\begin{array}{l}\text { No. tumors } \\
\text { formed / } \\
\text { No. mice } \\
\text { injected }\end{array}$ \\
\hline $\begin{array}{l}\text { I. Embryonic } \\
\text { Cell } \\
\text { Strains }\end{array}$ & $\begin{array}{l}\text { Balb / c } \\
\text { HFL-Johnson } \\
\text { HFL } 2\end{array}$ & $\begin{array}{l}\text { mouse embryo } \\
\text { human fetal lung } \\
\text { human fetal lung }\end{array}$ & $\begin{array}{l}\text { none } \\
\text { none } \\
\text { none }\end{array}$ & $\begin{array}{l}0 / 8 \\
0 / 13 \\
0 / 4\end{array}$ \\
\hline $\begin{array}{l}\text { II. Established } \\
\text { Lines of } \\
\text { Neoplastic } \\
\text { Origin }\end{array}$ & $\begin{array}{l}\text { RPMI } 2650 \\
\text { C6 } \\
\text { B-16 } \\
\text { HeLa } \\
\text { BRL-4143 }\end{array}$ & $\begin{array}{l}\text { human carcinoma } \\
\text { rat glioma } \\
\text { mouse melanoma } \\
\text { human carcinoma } \\
\text { human melanoma }\end{array}$ & $\begin{array}{l}\text { spontaneous } \\
\text { N-nitro- } \\
\text { somethylurea } \\
\text { spontaneous } \\
\text { spontaneous } \\
\text { spontaneous }\end{array}$ & $\begin{array}{c}8 / 9 \\
10 / 10 \\
\\
20 / 20 \\
15 / 15 \\
5 / 16\end{array}$ \\
\hline $\begin{array}{l}\text { III. Established } \\
\text { Lines from } \\
\text { Normal } \\
\text { Tissue }\end{array}$ & $\begin{array}{l}\text { Balb / c 3T3 } \\
\text { MDCK } \\
\text { BRL } \\
\text { 31A } \\
\text { 3T6 }\end{array}$ & $\begin{array}{l}\text { mouse embryo } \\
\text { dog kidney } \\
\text { rat liver } \\
\text { rat ovary } \\
\text { mouse embryo }\end{array}$ & $\begin{array}{l}\text { none } \\
\text { none } \\
\text { none } \\
\text { none } \\
\text { none }\end{array}$ & $\begin{array}{l}0 / 12 \\
0 / 16 \\
0 / 20 \\
0 / 12 \\
7 / 7\end{array}$ \\
\hline $\begin{array}{l}\text { IV. Lines } \\
\text { Trans- } \\
\text { formed } \\
\text { in vitro }\end{array}$ & $\begin{array}{l}\text { SVT2 } \\
\text { 56-1 } \\
\text { T } \\
\text { XIII } \\
\text { VA2-8-aza-Gr } \\
\text { RBSV3 } \\
\text { RBSV-1A } \\
\text { LNSV } \\
\text { PY 3T3 } \\
\text { A-9 } \\
\text { WI-L2 }\end{array}$ & $\begin{array}{l}\text { mouse embryo } \\
\text { mouse embryo } \\
\text { mouse embryo } \\
\text { mouse embryo } \\
\text { human fetal lung } \\
\text { human skin } \\
\text { human fetal lung } \\
\text { human skin } \\
\text { mouse embryo } \\
\text { mouse muscle }\end{array}$ & $\begin{array}{l}\mathrm{SV}_{40} \\
\mathrm{SV}_{40} \\
\mathrm{SV}_{40} \\
\mathrm{SV}_{40} \\
\mathrm{SV}_{40} \\
\mathrm{SV}_{40} \\
\mathrm{SV}_{40} \\
\mathrm{SV}_{40} \\
\text { polyoma } \\
\text { methyl- } \\
\text { cholanthrine } \\
\text { spontaneous }\end{array}$ & $\begin{array}{c}10 / 10 \\
10 / 10 \\
10 / 10 \\
10 / 10 \\
0 / 12 \\
0 / 12 \\
0 / 10 \\
0 / 6 \\
5 / 5 \\
10 / 10\end{array}$ \\
\hline
\end{tabular}

Table 1: Tumorigenicity of heterologous cells in athymic nude mice. The tumorigenic potential of the various cell lines was examined by injecting from $10^{6}$ to $2 \times 10^{6}$ viable cells subcutaneously into the scapular region. All cell lines were tested in both male and female mice. Cell lines were classed as tumorigenic when nodules grew progressively to greater than $5 \mathrm{~mm}$ in diameter at the site of injection. Most tumorigenic cell lines produced tumors from 7 to 21 days post inoculation. Mice injected with RPMI 2650 developed tumors in 20 to 60 days. Before cell lines were classed as nontumorigenic, the test animals were observed for at least four months and a second series of nude mice was challenged with a larger cell inoculum $\left(5 \times 10^{6}\right.$ to $10^{7}$ cells). 


\section{Results}

\section{Tumorigenicity of Heterologous Cells in Nude Mice}

Table 1 summarizes the tumorigenic potential of heterologous cell lines in athymic nude mice. Embryonic cell strains never grew tumors in nude mice. All established cell lines of neoplastic origin were tumorigenic. Established cell lines derived from explants of nonneoplastic animal tissue were generally not tumorigenic. Every line of SV40 transformed mouse cells tested was tumorigenic. Curiously, none of 5 lines of SV40 transformed human cells produced tumors even though each of 3 human lines derived from authentic neoplasms and a line of human lymphocytes from a non-leukemic patient were tumorigenic. Dr. James Robb at the University of California, San Diego School of Medicine kindly screened the SV40 transformed human lines for the presence of viral $\mathrm{T}$ antigen by immunofluorescence and found all of them to be T-antigen positive.

\section{Basis of Growth Suppression in Nude Mice}

A variety of control experiments indicated that the failure of particular cell lines to grow tumors in nude mice was not a trivial result but rather indicated an authentic response to host mediated growth regulatory signals.

Attempts to "vaccinate" nude mice against human tumor cells (Hela) by repeated inoculation of normal human lung fibroblasts in Freund's adjuvant were unsuccessful. Mice which had been inoculated with human fetal lung cells in Freund's adjuvant were bled and the serum was tested for the presence of cytotoxic antibodies directed either against fetal lung cells or against Hela cells. No evidence of cytotoxic antibodies directed against either cell type was found. These experiments indicate that the failure of human fetal lung cells to grow tumors in nude mice is not due to rejection by either the cell mediated or humoral immune response.

\section{Fate of Nontumorigenic Cells in Nude Mice}

The hairless condition of these athymic animal hosts facilitates observation of nontumorigenic cells which are injected subcutaneously. An inoculum of $10^{8}$ cells is visable as a light colored subcutaneous mass from one to two $\mathrm{mm}$ in diameter twenty four hours after injection. The persistance of these masses is variable from cell line to cell line. Most nontumorigenic cells appear to survive no longer than 10 days beneath the skin of nude mice; however, an inoculum of $10^{6}$ dog kidney epithelial cells (MDCK) is still detectable in some animals at two months postinjection. One subcutaneous mass measuring $1.6 \mathrm{~mm}$ in diameter was removed from a mouse which had been injected with $10^{7} \mathrm{MDCK}$ cells two months previously. The tissue was plated into culture and cells with the MDCK epithelioid morphology were observed growing amid mouse fibroblasts. A clone of the epithelioid cells was isolated and metaphase chromosomes were stained with Geimsa. A modal chromosome number of 76 and the presence of a large metacentric $\mathrm{X}$ chromosome (fig. 1) identified the cells as MDCK. Thus cell lines which do not induce pro- 
gressively growing tumors can persist for long periods of time in nude mice and be recovered in a viable state.

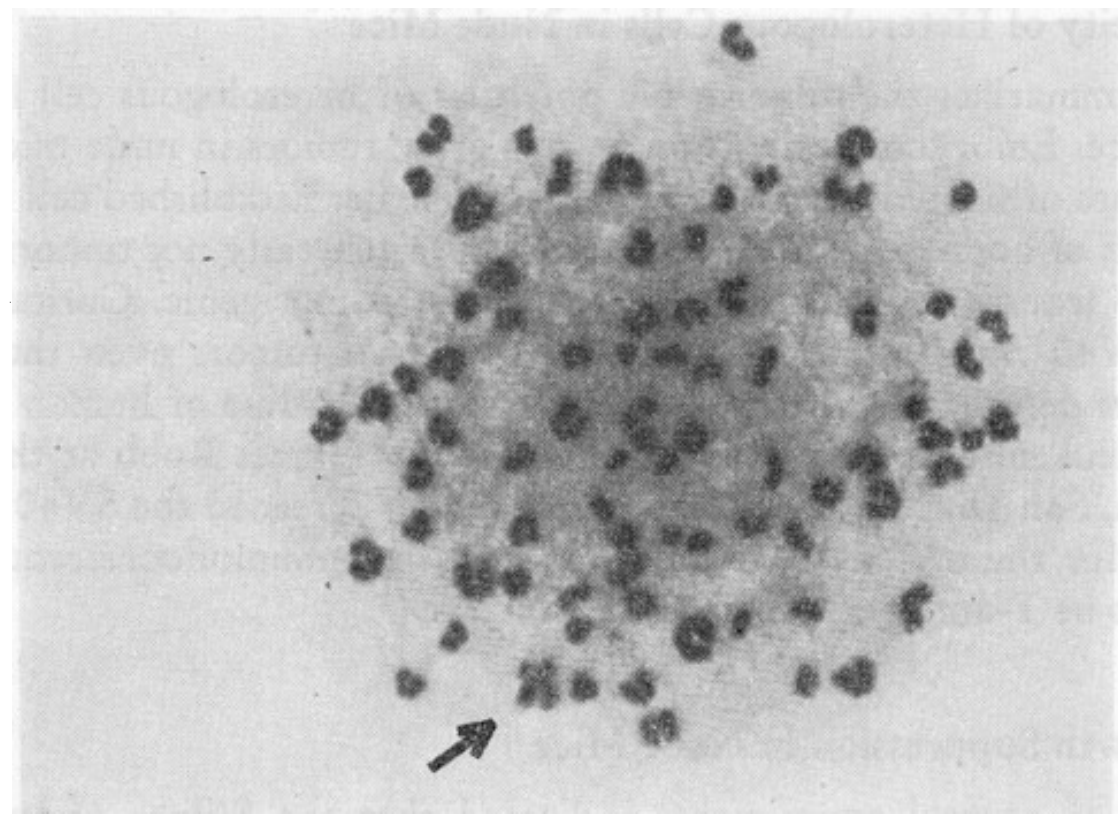

Fig. 1: Metaphase cell recovered from a nude mouse injected two months previously with MDCK dog kidney cells. The arrow indicates the large metacentric $\mathrm{X}$ chromosome which characterizes the canine karyotype.

* In each experiment, one C57 mouse died prior to three weeks and could not be autopsied

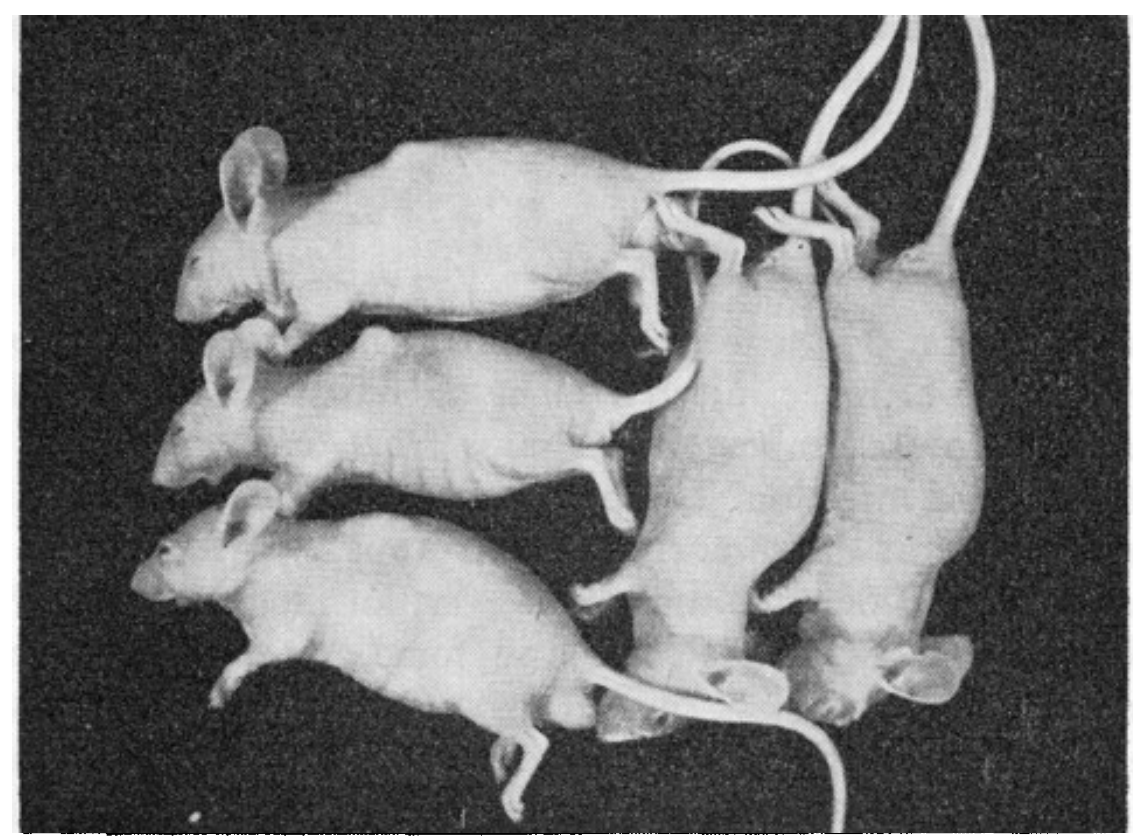

Fig. 2: The three mice on the left received $10^{6}$ MDCK cells subcuntaneously along the midline of the back one day after birth. The two mice on the right received $2 \times 10^{6} \mathrm{MDCK}$ cells subcutaneously on the right flank as adults. The mice on the left were photographed 30 days after injection and the mice on the right were photographed 60 days after injection. 


\section{Growth Response of Nontumorigenic Cells in Nude Mice}

MDCK cells did not induce tumors when injected into nude mice. Previous experiments indicated that nude mice do not reject heterologous cells immunologically and it was shown that MDCK cells surived for long periods in nude mice with no net growth. To determine whether the MDCK line could respond to host growth regulatory signals, $10^{6}$ cells were injected subcutaneously into 1 day old nude mice. At birth the nude mouse weighs approximately 1 gram and over the next 30 days, mass increases to about 20 grams. Figure 2 demonstrates that in rapidly growing mice inocula of $10^{6} \mathrm{MDCK}$ cells formed nodules measuring $0.5 \mathrm{~cm}$ in diameter whereas twice as many cells injected into adult animals failed to grow. MDCK nodules formed in neonatal animals did not continue to grow once the animals attained adult mass. Thus the failure of MDCK cells to grow tumors in nude mice does not seem to be caused by rejection or any intrinsic deficiency on the part of the host. Rather these cells seem responsive to host mediated growth regulatory signals.

\section{Relationship of Growth Behavior in vitro to Tumorigenicity}

The observation that 5 human cell lines infected with, and morphologically transformed by SV40 virus were not tumorigenic suggested that many of those characteristics which serve to define the transformed state in vitro are only

Table II

\begin{tabular}{|c|c|c|c|c|c|}
\hline & Cell Line & $\begin{array}{l}\text { Growth in } \\
1 \% \text { fetal } \\
\text { calf serum }\end{array}$ & $\begin{array}{l}\text { Saturation } \\
\text { density } \\
\text { greater than } \\
10^{5} \text { cells } / \mathrm{cm}^{2}\end{array}$ & $\begin{array}{l}\text { Growth in } \\
\text { methocel } \\
\text { suspension }\end{array}$ & $\begin{array}{l}\text { Growth on } \\
\text { confluent } \\
\text { mouse cell } \\
\text { monolayers }\end{array}$ \\
\hline $\begin{array}{l}\text { Tumor- } \\
\text { igenic } \\
\text { Cell } \\
\text { Lines }\end{array}$ & $\begin{array}{l}\text { 3T6 } \\
\text { RPMI-2650 } \\
\text { Hela } \\
\text { BRL-4143 } \\
\text { C-6 } \\
\text { B-16 } \\
\text { SVT2 } \\
\text { PY3T3 } \\
\text { A-9 }\end{array}$ & $\begin{array}{l}+ \\
+ \\
+ \\
+ \\
+ \\
- \\
+ \\
+ \\
+\end{array}$ & $\begin{array}{l}+ \\
+ \\
+ \\
- \\
+ \\
+ \\
+ \\
+ \\
+\end{array}$ & $\begin{array}{l}- \\
+ \\
+ \\
+ \\
+ \\
+ \\
- \\
+ \\
+\end{array}$ & $\begin{array}{l}+ \\
+ \\
+ \\
+ \\
+ \\
+ \\
+ \\
+ \\
+\end{array}$ \\
\hline $\begin{array}{l}\text { Non- } \\
\text { tumor- } \\
\text { igenic } \\
\text { Cell } \\
\text { Lines }\end{array}$ & $\begin{array}{l}3 \text { T3 } \\
\text { MDCK } \\
\text { 31A } \\
\text { BRL } \\
\text { VA2-8-azaGr } \\
\text { LNSV }\end{array}$ & $\begin{array}{l}- \\
+ \\
- \\
+ \\
-\end{array}$ & $\begin{array}{l}- \\
+ \\
+ \\
+ \\
+ \\
+\end{array}$ & $\begin{array}{l}- \\
+ \\
- \\
\overline{+} \\
-\end{array}$ & $\begin{array}{l}- \\
+ \\
+ \\
+ \\
+ \\
+\end{array}$ \\
\hline
\end{tabular}

Table2: Correlation of growth behavior in vitro with tumorigenicity in nude mice. 
coincidentally related to malignant potential in animals. The serum growth requirement, the ability to grow on top of stationary phase mouse monolayer cultures, the ability to grow in methocel suspension and the cell saturation density were determined for various cell lines. The correlation of these in vitro growth parameters with tumorigenicity in athymic nude mice is summarized in table 2. As can be seen, there is no absolute correlation between any in vitro growth parameter and tumorigenic potential in immunologically tolerant hosts. In fact with the exception of secondary mouse embryo fibroblasts and 3T3 cells, every nontumorigenic cell line displayed one or more of those cell growth characteristics in vitro which have come to be associated with the transformed state.

\section{Suppression of Metastasis in the Nude Mouse}

In the course of testing various cell lines for tumorigenicity we were struck with the complete absence of tumor metastasis in these athymic hosts. Despite the diverse origin of the nine tumor producing lines depicted in table 1 and the large number of animals tested, tumor growth was always restricted to the region where cells were inoculated. To investigate this phenomenon in more detail, the malignant potential of a highly metastatic subclone of the B-16 mouse melanoma was tested in nude mice. B-16 melanoma clone \#2 cells: were derived by inoculating tumor cells subcutaneously into $\mathrm{C} 57$ black mice and culturing the metastatic nodules which arose in occasional animals. The parental B-16 line seldom metastasized in C57 black mice whereas within 3 weeks the B-16 clone \#2 cells metastasized to the lungs, lymph nodes and spleen of sixty percent of the animals tested (table 3 and

\section{Table III}

\begin{tabular}{|c|c|c|c|c|c|c|}
\hline \multirow{2}{*}{$\begin{array}{l}\text { B-16 } \\
\text { Cell } \\
\text { Clone }\end{array}$} & \multicolumn{3}{|c|}{ C57 Mouse } & \multicolumn{3}{|c|}{ Nude Mouse } \\
\hline & $\begin{array}{l}\# \text { mice } \\
\text { injected }\end{array}$ & $\begin{array}{l}\text { mean } \\
\text { tumor } \\
\text { mass at } \\
\text { autopsy }\end{array}$ & $\begin{array}{l}\text { \# mice } \\
\text { with } \\
\text { metastatic } \\
\text { nodules }\end{array}$ & $\begin{array}{l}\text { \# mice } \\
\text { injected }\end{array}$ & $\begin{array}{l}\text { mean } \\
\text { tumor } \\
\text { mass at } \\
\text { autopsy }\end{array}$ & $\begin{array}{l}\text { \# mice } \\
\text { with } \\
\text { metastatic } \\
\text { nodules }\end{array}$ \\
\hline$B-16 \# 2$ & 9 & $1.0 \pm 1.0 \mathrm{~g}$ & 6 & 10 & $1.6 \pm 1.2 \mathrm{~g}$ & 1 \\
\hline B-16 \#2s & 10 & $2.0 \pm 0.85 \mathrm{~g}$ & 8 & 10 & $3.7 \pm 0.5 \mathrm{~g}$ & 0 \\
\hline
\end{tabular}

Table 3: Suppression of metastasis in nude mice. Two highly invasive subclones of the B-16 mouse melanoma were injected subcutaneously into the scapular region of C57 black mice or into nude mice. Each mouse received $10^{6}$ cells and all mice developed tumors. At three weeks postinjection the animals were sacrificed. Tumors were weighed and the animals were examined for black melanoma nodules in the lungs, lymph nodes and spleens.

fig. 3). In athymic nude mice, B-16 clone \#2 cells induce large pigmented tumors (table 3 ) but, with one exception in 20 challenges, none of the nude mice showed secondary tumor metastasis at autopsy (table 3 ).

One clue to the mechanism whereby metastasis is suppressed in athymic nude mice may be found in the growth behavior of human lymphocytes in these animal 

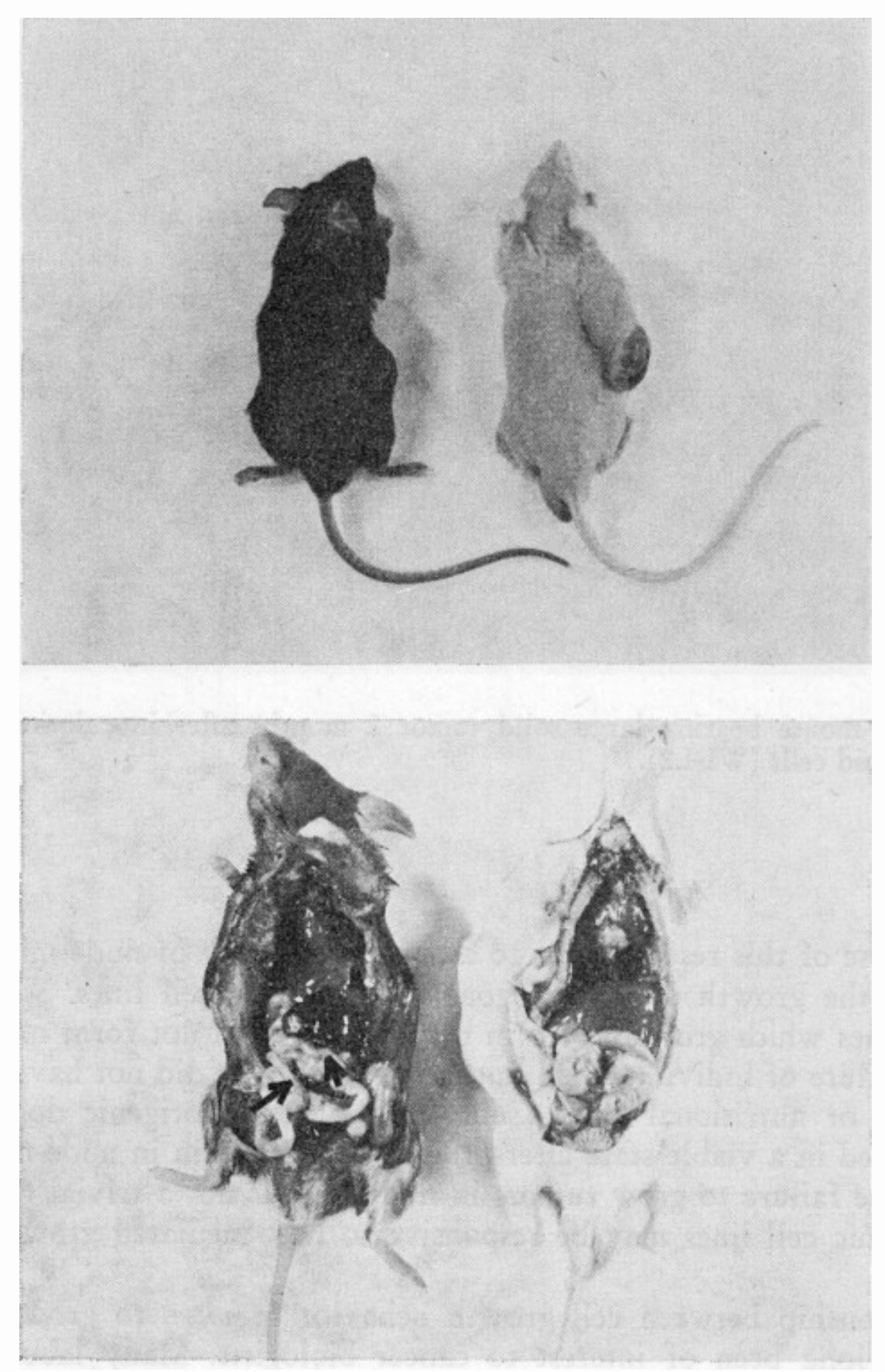

Fig. 3: Top; C57 mouse on left and nude mouse on right, 3 weeks following injection of $10^{8} \mathrm{~B}-16$ clone \# $2_{\mathrm{s}}$ cells. Arrows indicate large pigmented tumors growing at site of injection in animals. Bottom; Same animals as above after dissection. Arrows indicate metastatic melanoma nodules in C57 mouse. No metastasis was detectable in the nude mouse.

hosts. The WI-L2 cell line was derived from spleen cells of a patient free from malignant disease but bearing antibodies to Epstein Barr virus. In culture the cells grow entirely in suspension showing no tendency to adhere to coated plastic tissue culture dishes. WI-L2 cells are tumorigenic in nude mice but the tumors formed are solid lymphosarcomas (fig. 4). No ascites formation was noted in 4 nude mice injected intraperitonially with two million cells per mouse. 


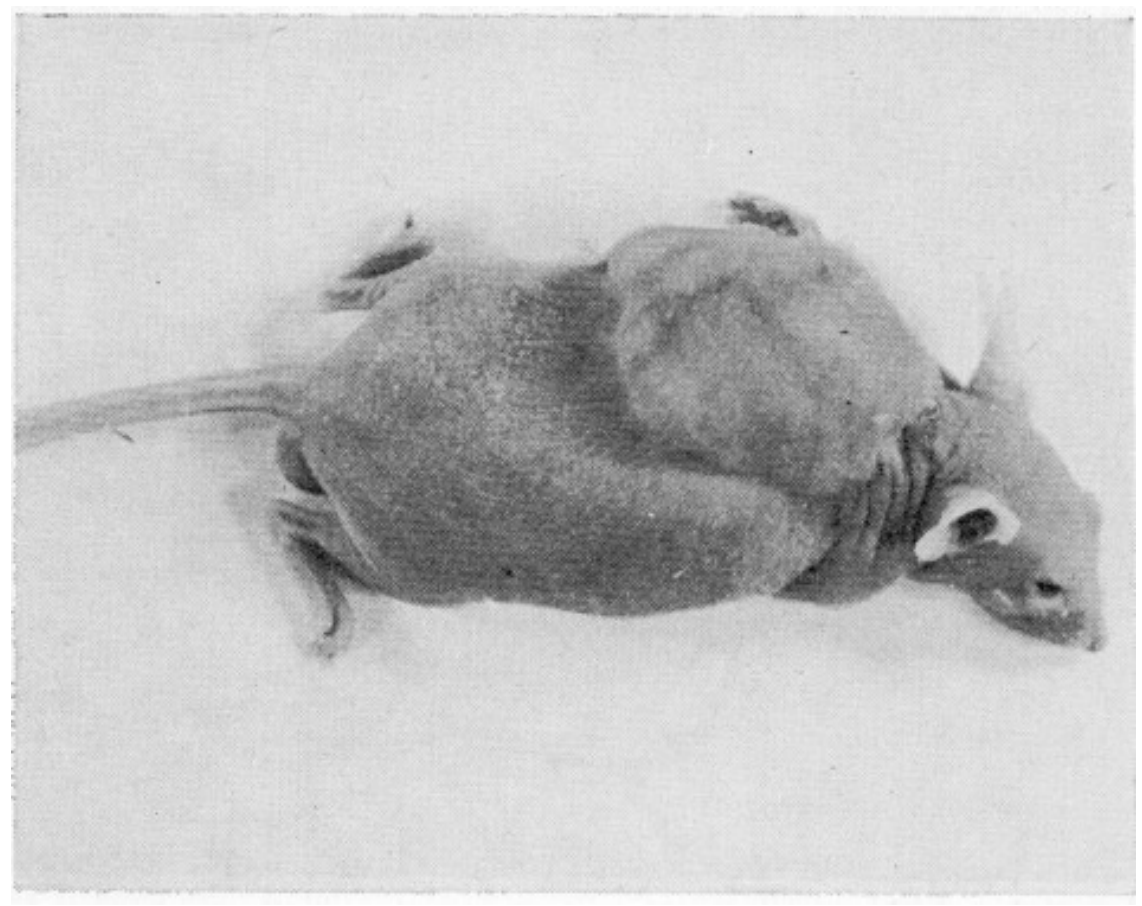

Fig. 4: Nude mouse bearing large solid tumor 2 months after inoculation with $2 \times 10^{6}$ human lymphoid cells (WI-L2).

\section{Discussion}

The purpose of this research was to assess the capacity of nude mice to support and control the growth of heterologous tissue culture cell lines. We found that many cell lines which grow forever in tissue culture did not form tumors in nude mice. The failure of individual cell lines to grow tumors did not have an apparent immunologic or nutritional basis. Cells from a nontumorigenic dog kidney line were recovered in a viable state after prolonged incubation in nude mice. We conclude that the failure to grow tumors in nude mice is not a trivial result. Rather, nontumorigenic cell lines may be responsive to host mediated growth regulatory signals.

The relationship between cell growth behavior in vitro to growth control in animals has long been of interest to cancer biologists. Many laboratories have sought to determine whether growth behavior in vitro correlates with tumorigenicity in animal hosts; the published conclusions are at variance. Aaronson and Todaro (1963) concluded that the ability to grow to high saturation density correlated best with tumorigenicity. Weiss et al. (1973) suggested that loss of contact inhibition of growth and of locomotion was the best indicator of tumorigenic potential. Di Mayorca et al. (1973) and Freedman and Shin (1974) have concluded that loss of anchorage requirement is essential to tumorigenicity. The congenitally athymic nude mouse would seem to be the most useful animal host for correlative studies between growth behavior in vitro and tumorigenicity; in the immunologically tolerant nude mouse, a cellular growth response in the host cannot be masked by a host immune response to the cells. We have found that under uniform culture conditions, none of those in vitro growth parameters which serve to define "transformation" in tissue culture correlate with tumorigenicity in nude mice. These 
experiments indicate that the most reliable and physiologically meaningful assay for malignant transformation may be cell tumorigenicity in nude mice.

The pathologic consequences of malignant transformation are more a reflection of tumor cell invasiveness than of tumor growth potential (Kark, W. 1966). The mechanisms whereby malignant tumor cells migrate through surrounding tissue, penetrate the blood vascular and lymphatic systems and lodge at distal sites to form secondary tumors are difficult to study in tissue culture. Growth of malignant tumors in heterologous animal hosts, wherein the origin of distal metastasis may be determined unambiguously, may provide insight into these problems. Giovionella (1973) reported the occurrence of metastasis from a human melanoma in athymic nude mice. On the other hand, this laboratory and others (Freedman and Shin, 1974) have not observed metastasis in nude mice, although more than 50 human and animal cell lines have been studied. A direct test of metastatic potential in nude mice using mouse melanoma cells of proven invasive capabilities confirmed that metastasis is suppressed in athymic nude mice (table 4 and fig. 2). These observation corroborate the finds of Fidler (1974) who, in a series of experiments using B-16 melanoma cells with properties similar to those described here, found that low numbers of lymphocytes from tumor bearing animals actually promoted metastasis in thymectomized -X-irradiated C57 mice.

The incongruous growth behavior of human lymphocytes, which formed solid tumors in nude mice while growing as suspension cells in tissue culture may provide a clue to the supression of metastasis. Freedman and Shin (1974) reported a similar modification of growth behavior for Erlich Ascites cells which grew only as solid tumors in nude mice. These results suggest that a thymus dependent function is required in order for cells to grow in suspension in animal hosts.

The experiments described in this communication demonstrate that the growth behavior of cells in tissue culture is in many respects not indicative of their behavior in animals. It is likely that growth of normal animal tissues is regulated by hormone like agents and cellular interactions which have yet to be described in vitro. Observations on the growth of heterologous tissue culture cell lines in immunologically tolerant nude mice may assist in the reconstruction of these growth regulatory interactions in vitro.

\section{Acknowledgements}

This research was supported by Special Grant \#741 from the California Division of the American Cancer Society, a grant from the University of California Cancer Research Coordinating Committee and NIH grant \#15503-02. M.H.S. is supported by Career Development Award CA001138-01. C.D.S. is supported by a postdoctoral fellowship award from the USPHS \#DE03366.

\section{Bibliography}

Aaronson, S. A. and Todaro, G. J. 1968. Basis for Acquisition of Malignant Potential by Mouse Cells Cultivated in vitro. Science, 162: 1024-1026.

Di Mayorca, G., Greenblatt, M., Frauthen, T., Loller, A., and Giordano, R. 1973. Malignant Transformation of $\mathrm{BHK}_{21}$, Clone 13 Cells in vitro by Nitrosamines A Conditional State. Proc. Nat. Acad. Sci. U.S.A., 70: 46-49. 
Freedman, V. H. and Shin, S. 1974. Cellular Tumorigenicity in Nude Mice: Correlation with Growth in Semi-Solid Medium. Cell, 3: 355-359.

Fidler, I. J., 1974. Immune Stimulation-Inhibition of Experimental Cancer Metastasis. Cancer Res., 34: 491-498.

Furth, J. 1967. Pioitary Cybernetics and Neoplasia. Harvey Lectures, 63: 47-72.

Giovannella, B. C., Yim, S. O., A. C. Morgan, J. S. Stehlin and L. J. Williams, Jr. 1973. Brief Communication: Metastases of Human Melanoma Transplanted in "nude" Mice. J. Nat. Cancer Inst., 48: 1531-1533.

Karl, W. 1966. A Synopsis of Cancer. Williams and Wilkinson Co.

Rygaard, J. 1973. Thymus and Self. F.A.D.L. Copenhagen (C) 1973 Jørgen Rygaard, Copenhagen, Henmark.

Weiss, R. A., Vesely, P. and Sindelarova, J. 1973. Growth Regulation and Tumor Formation of Normal and Neoplastic Rats Cells. INT. J. Cancer, 11: 77-89. 